\title{
HISTORICAL HYDRONUCLEAR TESTING: CHARACTERIZATION AND REMEDIATION TECHNOLOGIES
}

\author{
prepared by \\ RECEIVED \\ FEB 021998 \\ Lynn Shaulis, Glenn Wilson and Roger Jacobson \\ OSTI
}

submitted to

Nevada Operations Office

U.S. Department of Energy

September 1997

Distribution of this document is UNLIMITED $p^{2}$ MASTER

Publication No. 45158 
This report was prepared as an account of work sponsored by the United States Government. Neither the United States nor the United States Department of Energy, nor any of their employees, makes any warranty, express or implied, or assumes any legal liability or responsibility for the accuracy, completeness or usefulness of any information, apparatus, product or process disclosed, or represents that its use would not infringe privately owned rights. Reference herein to any specific commercial product, process, or service by trade name, mark, manufacturer, or otherwise, does not necessarily constitute or imply its endorsement, recommendation, or favoring by the United States Government or any agency thereof. The views and opinions of authors expressed herein do not necessarily state or reflect those of the United States Government or any agency thereof.

This report has been reproduced directly from the best available copy.

Available to DOE and DOE contractors from the Office of Scientific and Technical Information, P.O. Box 62, Oak Ridge, TN 37831; prices available from (423) 576-8401.

Available to the public from the National Technical Information Service, U.S. Department of Commerce, 5285 Port Royal Rd., Springfield, VA 22161. 


\section{DISCLAIMER}

Portions of this document may be illegible electronic image products. Images are produced from the best available original document. 
DOE/NV/1 1508-28

UC-703

\title{
HISTORICAL HYDRONUCLEAR TESTING: CHARACTERIZATION AND REMEDIATION TECHNOLOGIES
}

\author{
prepared by \\ Lynn Shaulis, Glenn Wilson and Roger Jacobson \\ Desert Research Institute \\ University and Community College System of Nevada
}

Publication No. 45158

submitted to

Nevada Operations Office

U.S. Department of Energy

Las Vegas, Nevada

September 1997

The work upon which this report is based was supported by the U.S. Department of Energy under Contract \#DE-AC08-95NV11508. 


\section{ACKNOWLEDGMENTS}

This report would not be possible without the funding from DOE Contract \#DE-AC0895NV11508. The assistance of Mr. Jim Cebe and Ms. Pat Bodin of the DOE Nevada Operations Office and Dr. Bill Johnson of the Desert Research Institute is gratefully acknowledged. 


\begin{abstract}
This report examines the most current literature and information available on characterization and remediation technologies that could be used on the Nevada Test Site (NTS) historical hydronuclear test areas. Historical hydronuclear tests use high explosives and a small amount of plutonium. The explosion scatters plutonium within a contained subsurface environment. It is believed that most of the historical hydronuclear tests were performed either in alluvial materials or a sandy tuffaceous unit that is moderately to well indurated. There is currently a need to characterize these test areas to determine the spatial extent of plutonium in the subsurface and whether geohydrologic processes are transporting the plutonium away from the event site. If movement of the plutonium has occurred or is likely to occur, it may be necessary to remediate the test areas to prevent future contamination.

Three technologies were identified to assist in the characterization of the sites. These technologies are the Pipe Explorer ${ }^{\mathrm{TM}}$, cone penetrometer, and drilling. The Pipe Explorer ${ }^{\mathrm{TM}}$, which is the only noninvasive technique, would deploy sensors into the test boreholes to measure radioactivity and provide video images of the borehole. Cone penetrometers can be fitted with several different sensors to provide estimates of various soil physical properties as well as measurements of radioactivity. Drilling technologies such as hollow stem auger and resonant sonic drilling would be used at test locations where it is not possible to use the Pipe Explorer ${ }^{\mathrm{TM}}$ or cone penetrometer, or if it is determined to be more cost effective.

If the characterization results indicate that remediation is needed, three remediation technologies were identified that should be appropriate, namely: capping or sealing the surface, in situ grouting, and in situ vitrification. Capping the surface would prevent vertical infiltration of water into the soil column, but would not restrict lateral movement of vadose zone water. Both the in situ grouting and vitrification techniques would attempt to immobilize the radioactive contaminants to restrict or prevent leaching of the radioactive contaminants into the groundwater. In situ grouting uses penetrometers or boreholes to inject the soil below the contaminant zone with low permeability grout. In situ vitrification melts the soil containing contaminants into a solid block. This technique would provide a significantly longer contaminant immobilization, but some research and development would be required to re-engineer existing systems for use at deep soil depths. Currently, equipment can only handle shallow depth vitrification. After existing documentation on the historical hydronuclear tests have been reviewed and the sites have been visited, more specific recommendations will be made.
\end{abstract}




\section{CONTENTS}

ACKNOWLEDGMENTS $\ldots \ldots \ldots \ldots \ldots \ldots \ldots \ldots \ldots \ldots \ldots \ldots \ldots \ldots$ ii

ABSTRACT $\ldots \ldots \ldots \ldots \ldots \ldots \ldots \ldots \ldots \ldots \ldots \ldots \ldots \ldots \ldots \ldots \ldots \ldots \ldots \ldots \ldots$

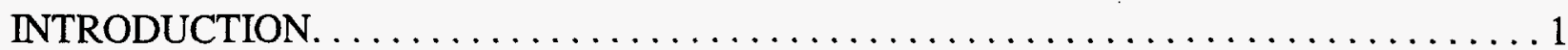

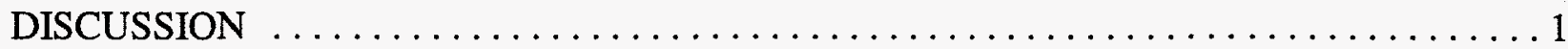

Characterization Technologies $\ldots \ldots \ldots \ldots \ldots \ldots \ldots \ldots \ldots \ldots \ldots \ldots \ldots \ldots \ldots$

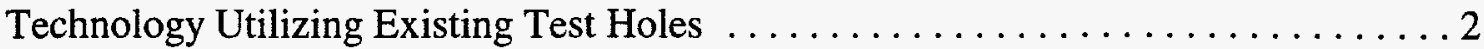

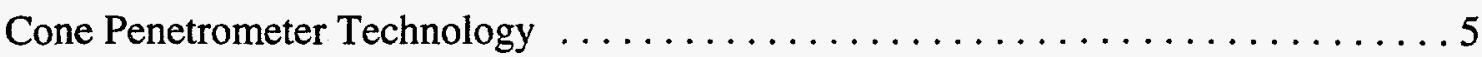

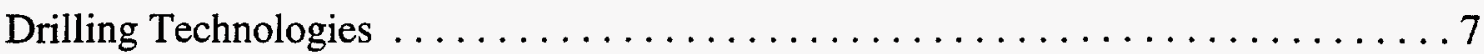

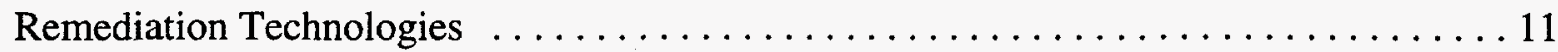

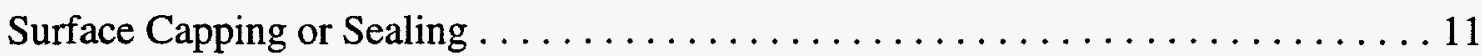

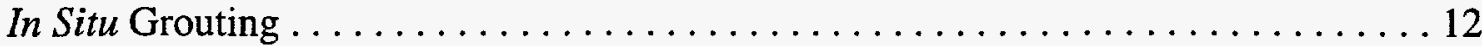

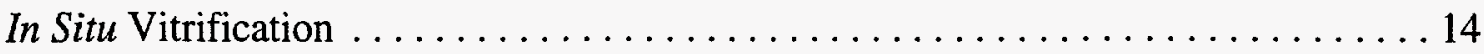

CONCLUSIONS AND RECOMMENDATIONS $\ldots \ldots \ldots \ldots \ldots \ldots \ldots \ldots \ldots \ldots$

CITATIONS AND OTHER REFERENCES $\ldots \ldots \ldots \ldots \ldots \ldots \ldots \ldots \ldots \ldots \ldots \ldots$

\section{LIST OF FIGURES}

1. Schematic depicting the deployment of the Pipe Explorer ${ }^{\mathrm{TM}}$ system $\ldots \ldots \ldots \ldots$

2. Survey of a drain line at the Formerly Utilized Sites Remedial Action Program

FUSRAP) site in Adrian MI with the Pipe Explorer ${ }^{\mathrm{TM}}$ system (solid line) $\ldots \ldots \ldots \ldots 4$

3. Schematic of a typical cone penetrometer system $\ldots \ldots \ldots \ldots \ldots \ldots \ldots \ldots$

4. Schematic of a sonic drill rig and the mechanism which produces a resonant wave $\ldots \ldots 8$

5. Cost comparison of drilling and completion costs for sonic and cable tool drilling . . . . 9

6. An illustration of the Geosafe large-scale in situ vitrification system . . . . . . . . . 14 


\section{INTRODUCTION}

At the present time, limited information has been declassified and released about the historical hydronuclear test locations, number of holes and characteristics, and therefore this investigation has been limited. It appears that tests were performed in several locations that include alluvial fans and a sandy tuffaceous unit that is moderately to well indurated. Based on this information, technologies have been investigated that could best be used to characterize any potential contamination of test holes located in these two types of materials ("best" is defined in this case as producing reliable data and is time and cost effective). Given that some of the test holes may be 14-27 $\mathrm{m}(45-90 \mathrm{ft})$ deep and the holes may or may not be sealed, the primary characterization technologies that are being examined include: drilling, cone penetrometers, and devices that can be lowered down the test holes, e.g., the Pipe Explorer ${ }^{\mathrm{TM}}$. The key limitation to the use of any characterization technology for this effort will be accessibility to the test holes. After the sites are visited and more background information is reviewed, it will be possible to provide more detailed recommendations on appropriate characterization and remediation technologies.

Based on the information known to date, remediation options may include: 1) no action; 2) capping or sealing the surface; and 3) in situ vitrification or grouting. Complete excavation of the test holes and surrounding material would be another option, but this type of remediation would be impractical and may not be justified by the potential low risk of radionuclide migration.

Information on characterization and remediation technologies have been gathered from the primary literature and Internet sources such as the: Global Network of Environmental Technology's Techknow Database; EM-50 Rainbow Book Series; Morgantown Federal Energy Technology Center; and numerous linked web sites. The focus was on technology that will permit characterization of the material in which the test holes were drilled and remediation of any potential contamination of the holes and surrounding material. This report does not address data interpretive strategies.

\section{DISCUSSION}

\section{Characterization Technologies}

To properly evaluate if remediation of historical hydronuclear test locations is necessary, it is important to: determine whether radioactive materials have moved since the test; the physical properties of the material in which the test holes were drilled; and whether any transport processes have or are likely to result in radionuclide migration. While existing classified reports from the period of testing may provide some of this information, it will be important to gather current information on the location of radioactive materials in and around the test holes and potential transport processes. The first step of the characterization phase should be the determination of the presence and location of radioactive materials. If radioactive materials are present, then characterization of the physical properties and potential for transport from a hydrogeological stand point will be required. The first part of this section will address technologies necessary to characterize radioactive contamination. 
One of the important factors that will have to be assessed is whether transport processes have caused or are likely to cause radioactive contamination to migrate. After the location of all historical hydronuclear test sites are declassified, it will be possible to ascertain if existing information is available on the hydrogeologic properties of those areas. If this information is not available, cores will have to be acquired to estimate water retention, runoff and hydraulic conductivity. It is possible that the test hole casing may act as a channel, allowing precipitation to rapidly infiltrate and permeate to the bottom of the test hole. A surface cap or seal will prevent rapid channelization of water to the bottom of the hole, but it will be necessary to measure the hydraulic conductivity of the test hole material to evaluate unsaturated flow rates.

\section{Technology Utilizing Existing Test Holes}

The least invasive characterization approach, if the test holes are not permanently sealed, includes technologies that use existing test boreholes to examine contamination at various depths. A few different technologies have been developed to examine pipe contamination. The only technology that has been found thus far that is transferrable to the historical hydronuclear test holes is called the Pipe Explorer ${ }^{\mathrm{TM}}$. This device can be lowered down any test hole or well, that is greater than $5 \mathrm{~cm}$ or 2 inches in diameter, with different sensor heads that can assess various types of radiation in the hole and possibly the surrounding material (if the contaminant has double peaks). The system does not require decontamination, as it remains inside a pressurized membrane when it is lowered and raised. The membrane is disposed of as a radioactive waste. Other technologies that were examined, such as the MICROSPI (multisensor inspection and characterization robot for small pipes), are not designed for vertical wells and require extensive decontamination. In addition to radiation sensors, a camera can be mounted on the Pipe Explorer ${ }^{\mathrm{TM}}$ head to visually inspect the interior of pipes and wells.

One of the DOE technical managers, Jim Kopotic, who was involved in the pilot testing of this system, stated that he was "very satisfied" with the technology, that it "far exceeded his expectations," and that the Pipe Explorer" "saved large amounts of money" on a study to examine radioactive contamination of a drainage system. The developer of this technology, Science and Engineering Associates, Inc. (SEA), Albuquerque, NM, has provided a video demonstration of the equipment that is attached to this report.

Figure 1 depicts how the Pipe Explorer ${ }^{\mathrm{TM}}$ works. The cannister is pressurized (1-5 psi), which causes a polyethylene membrane to be pushed from the cannister and inverted into the pipe or well to be examined. The membrane is pulled off the spool, at a speed of up to $9 \mathrm{~m} / \mathrm{min}$ ( $30 \mathrm{ft} / \mathrm{min}$ ), and inverted into the pipe until the pre-determined length of the membrane has been completely deployed; currently, the maximum length is $76 \mathrm{~m}(250 \mathrm{ft})$. The end of the membrane is sealed and tethered to a signal cable with attached sensor. As the second half of the membrane is deployed into the pipe, it pulls the sensor through the membrane-lined pipe until the membrane is completely inverted into the pipe. Depending on the diameter of the pipe, the Pipe Explorer ${ }^{\mathrm{TM}}$ can navigate $90^{\circ}$ turns. After the sensor has been deployed to the end of the membrane length, it is easily retrieved by winding the signal cable onto the spool. As the sensor is pulled back to the cannister, it collects data (video or abundance of radioactive contamination) and records the location where that data were 


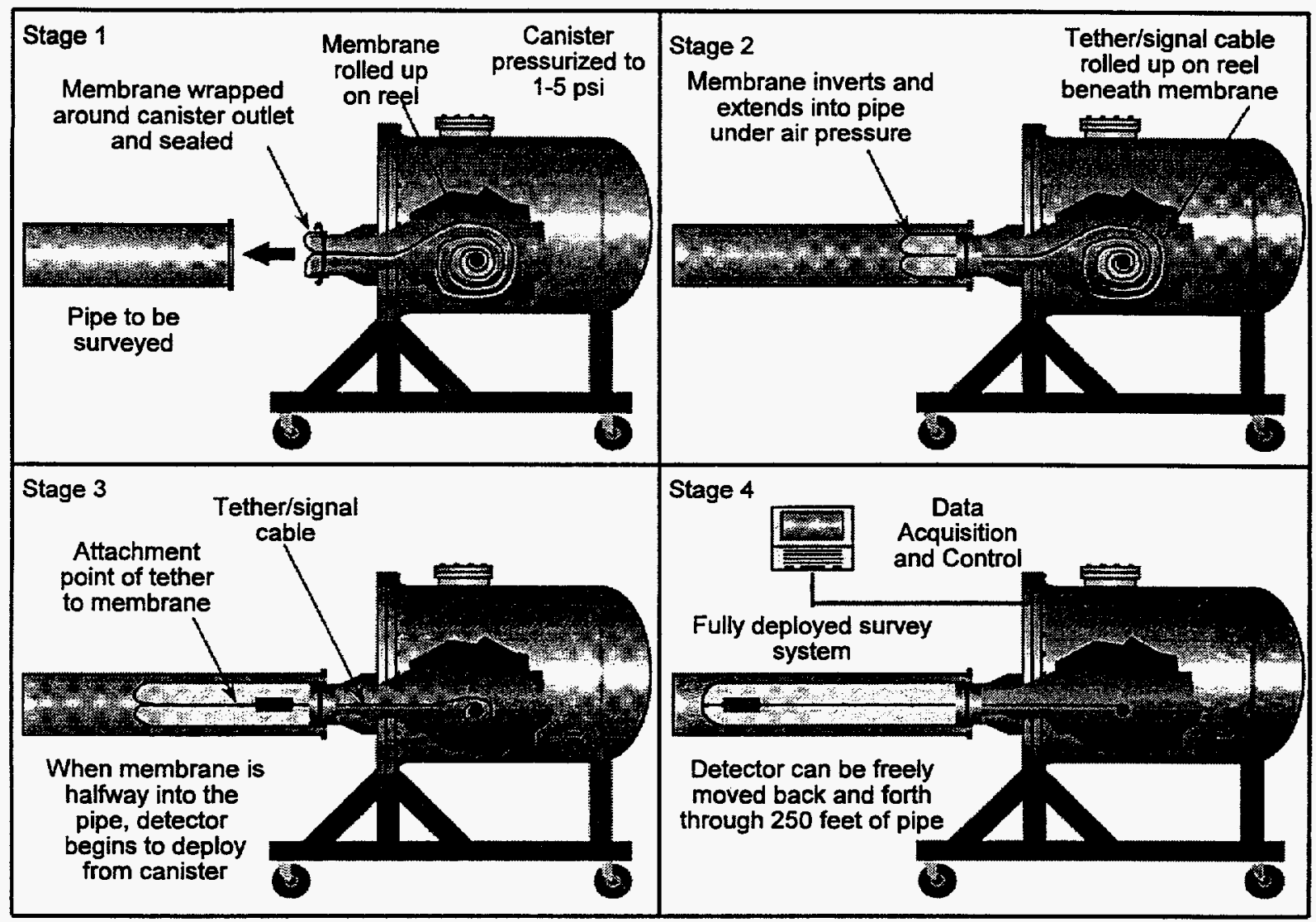

Figure 1. Schematic depicting the deployment of the Pipe Explorer ${ }^{\mathrm{TM}}$ system (from Kendrick and Cremer, 1996).

collected. This process is performed at a slower speed $(0.9 \mathrm{~m} / \mathrm{min}$ or $3 \mathrm{ft} / \mathrm{min})$ to ensure accuracy of measurements.

As the membrane is retrieved, the contaminated surface is inverted and becomes the interior side of the membrane. When the signal cable and sensor head have been wound back onto the spool, the membrane can be detached and wound onto a different spool for appropriate disposal. In this manner the signal cable, sensor head, and deploying cannister are protected from contamination.

The Pipe Explorer ${ }^{\mathrm{TM}}$ system can be used with any sensor that is small enough for the dimensions of the pipe to be characterized. For example, SEA has used the following sensors to date: a video camera (to examine pipe conditions); plastic scintillator beta/gamma probes; photomultiplier tubes for use with the alpha detection system; NaI(T1) and CsI(T1) gamma detectors; and pipe locator beacons. Figure 2 depicts the accuracy of the Pipe Explorer ${ }^{\mathrm{TM}}$ equipped with a beta probe. The hand survey measurements in this figure are consistently lower than the Pipe Explorer ${ }^{\mathrm{TM}}$ measurements, but this is to be expected as the retrieved membrane only picked up a portion of the radioactive material contained in the drainage pipe.

While the Pipe Explorer ${ }^{\mathrm{TM}}$ was developed to characterize potentially contaminated pipes, David Cremer, a senior scientist at SEA, stated that the pipe explorer would be applicable to the characterization of historical hydronuclear test holes. He stated that the alpha detector could provide 


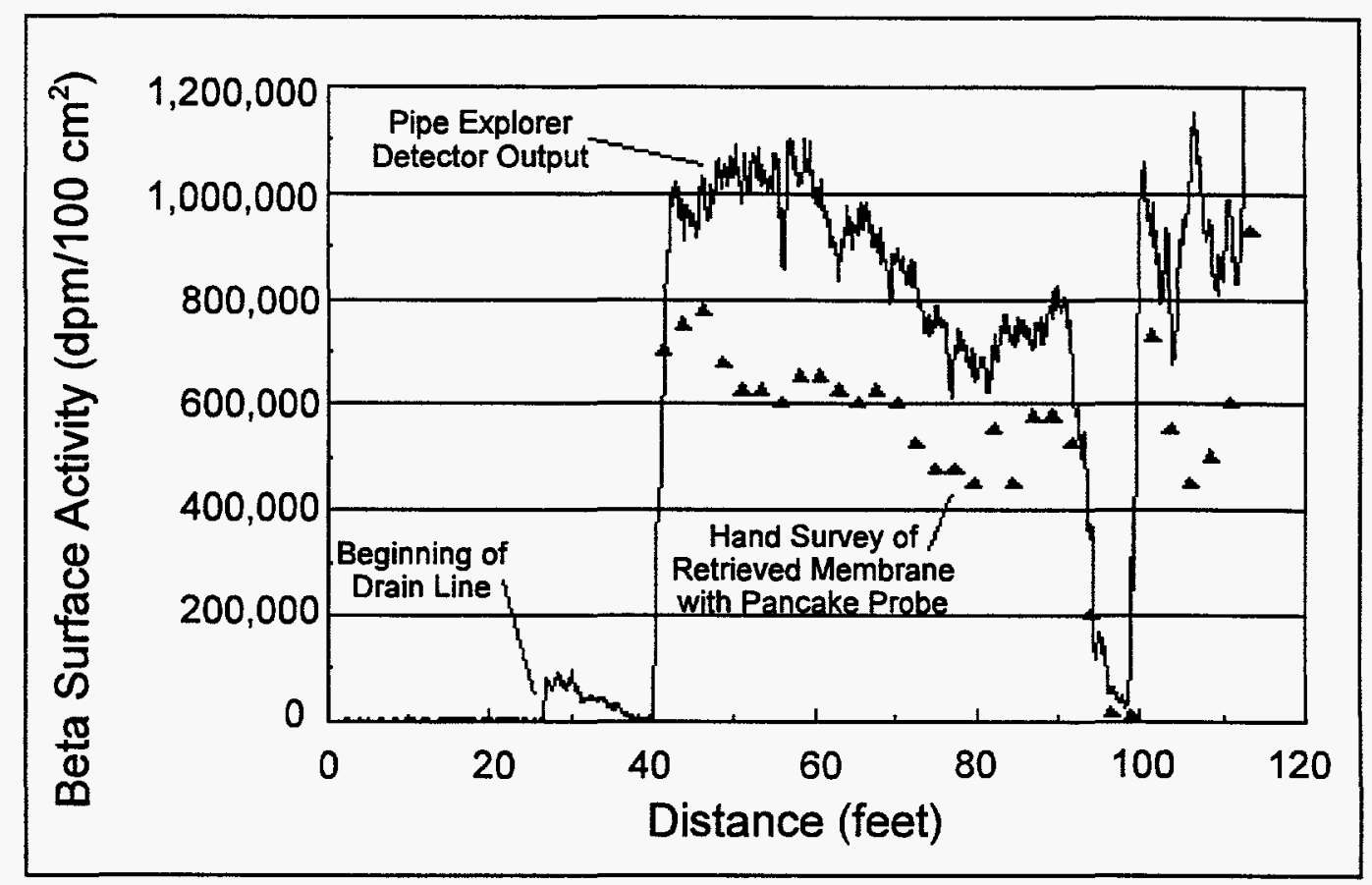

Figure 2. Survey of a drain line at the Formerly Utilized Sites Remedial Action Program (FUSRAP) site in Adrian, MI, with the Pipe Explorer ${ }^{\mathrm{TM}}$ system (solid line). Triangular data markers show measurements of contamination on the membrane retrieved from the drain line. (From DOE Office of Environmental Management, 1997a.)

information on radioactive contamination of the substrate in which the test holes were drilled. This could be evaluated by examining existing documentation of the historical hydronuclear test areas in a pre-characterization planning phase, and then conducting a field trial to determine the distance from the hole that radioactivity can be detected.

SEA states that the current cost to deploy the Pipe Explorer ${ }^{\mathrm{TM}}$ is $\$ 92 / \mathrm{m}(\$ 28 / \mathrm{ft})$, although they anticipate that the cost will drop to $\$ 36 / \mathrm{m}(\$ 11 / \mathrm{ft})$. This cost includes: a disposable membrane at $\$ 0.10 / \mathrm{m}$ ( $\$ 0.03 / \mathrm{ft})$; labor for a two-man crew; a $\$ 1000 /$ day rental rate for the equipment; and the travel per diem. As an example, a project that characterized a $396 \mathrm{~m}(1300 \mathrm{ft})$ drainage system in Grand Junction, CO, had a total cost of $\$ 36,000$ or $\$ 91 / \mathrm{m}(\$ 28 / \mathrm{ft})$.

There would be two approaches that could be used to detect plutonium using the Pipe Explorer $^{\mathrm{TM}}$, an alpha detector or a germanium gamma detector (Cremer, SEA, pers. comm., 1997). While an alpha detector can directly measure the presence of plutonium, any material, including air, between the detector and the contaminant would adversely impact the measurement. Therefore, a germanium gamma detector would provide the best measurement if there was sufficient plutonium present to provide sufficient gamma by-products. SEA has worked with a consultant who operates a germanium detector capable of detecting and locating plutonium contamination. A slit is placed on the detector to identify the location of the contaminant relative to the cardinal directions, i.e., north, south, east or west of the hole. In addition, it is possible to analyze the relative ratios of the gamma peaks to estimate the distance of the contaminant from the detector. The maximum distance that this detector is able to detect plutonium contamination is not known at this time for the NTS 
sites, however, this technology appears to provide a quick and relatively inexpensive means to assess the location of the plutonium used during the historical hydronuclear tests.

The contacts for this technology are David Cremer, SEA, (505)880-9852, and Jim Kopotic, DOE, (423)576-9441.

\section{Cone Penetrometer Technology}

If the test holes are permanently sealed or additional subsurface material characterization is required, two technologies have been identified to meet these potential needs, namely, cone penetrometers and drilling technologies. Geoprobes were briefly examined, but it was determined that the probability was very low for a geoprobe to penetrate the test area matrix materials to the desired depths. Cone penetrometers are more economical and less intrusive than drilling operations because the holes are smaller in diameter, drilling fluids are not required, and labor requirements are significantly reduced. While cone penetrometer technology has been used for soil physics and geotechnical applications for approximately 50 years, the use of cone penetrometers for environmental applications is relatively recent. Limited published information is available on the use of cone penetrometers for characterizing radioactive contamination; therefore, most of the text in this section is based on information acquired through Internet web sources.

Cone penetrometers are capable of pushing through fine soil particles and some gravel/cobble

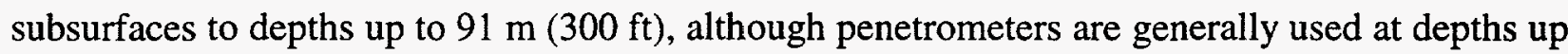

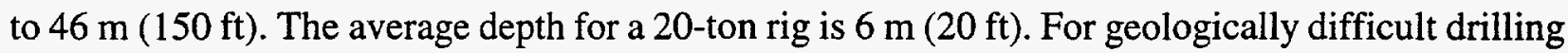
materials, resonant sonic and heavy-weight cone penetrometers have been developed. Water Development Corporation has developed a sonic-based push penetrometer system (no additional information could be found regarding this system). The heavy-weight cone penetrometer uses a 30ton rig. In 1992, this rig reached depths ranging from 1.8 to $44.8 \mathrm{~m}$ ( 6 to $147 \mathrm{ft}$ ), however at depths beyond $15 \mathrm{~m}(50 \mathrm{ft}$ ) the reliability (ability of the system to penetrate gravelly soils) drops to $50-75$ percent.

Figure 3 depicts a typical cone penetrometer setup which consists of a 20 - to 40 -ton truck equipped with vertical hydraulic rams which push a sensor probe into the ground, and a data acquisition and analysis system. Cone penetrometers have penetration rates as high as $91 \mathrm{~m} / \mathrm{hr}$ (300 $\mathrm{ft} / \mathrm{hr}$ ), but the typical rate ranges from 12 to $15 \mathrm{~m} / \mathrm{hr}(40-50 \mathrm{ft} / \mathrm{hr})$. ASTM standards require a maximum push rate of $0.02 \mathrm{~m} / \mathrm{s}$ for data collection.

Various sensors can be used in conjunction with cone penetrometers. The typical sensors include: two-axis inclinometers, an acoustic cone to identify soil type, temperature, $\mathrm{pH}$, and geophones to measure pressure and shear waves (i.e., seismic). Special application sensors to detect soil moisture and chemical and radiation contamination have been or are under development for use with a cone penetrometer. These include: the SCAPS LIF (Site Characterization and Analysis Penetration System Laser-Induced Fluorescence) and ROST ${ }^{\mathrm{TM}}$ (Rapid Optical Screening Tool) probes that detect petroleum hydrocarbons; TDR (Time Domain Reflectrometry ) and Fiber Optic RH (Relative Humidity) probes that detect soil moisture; electrochemical sensors which detect explosives such as TNT; and radiation probes to detect radioactive contamination and soil density. 


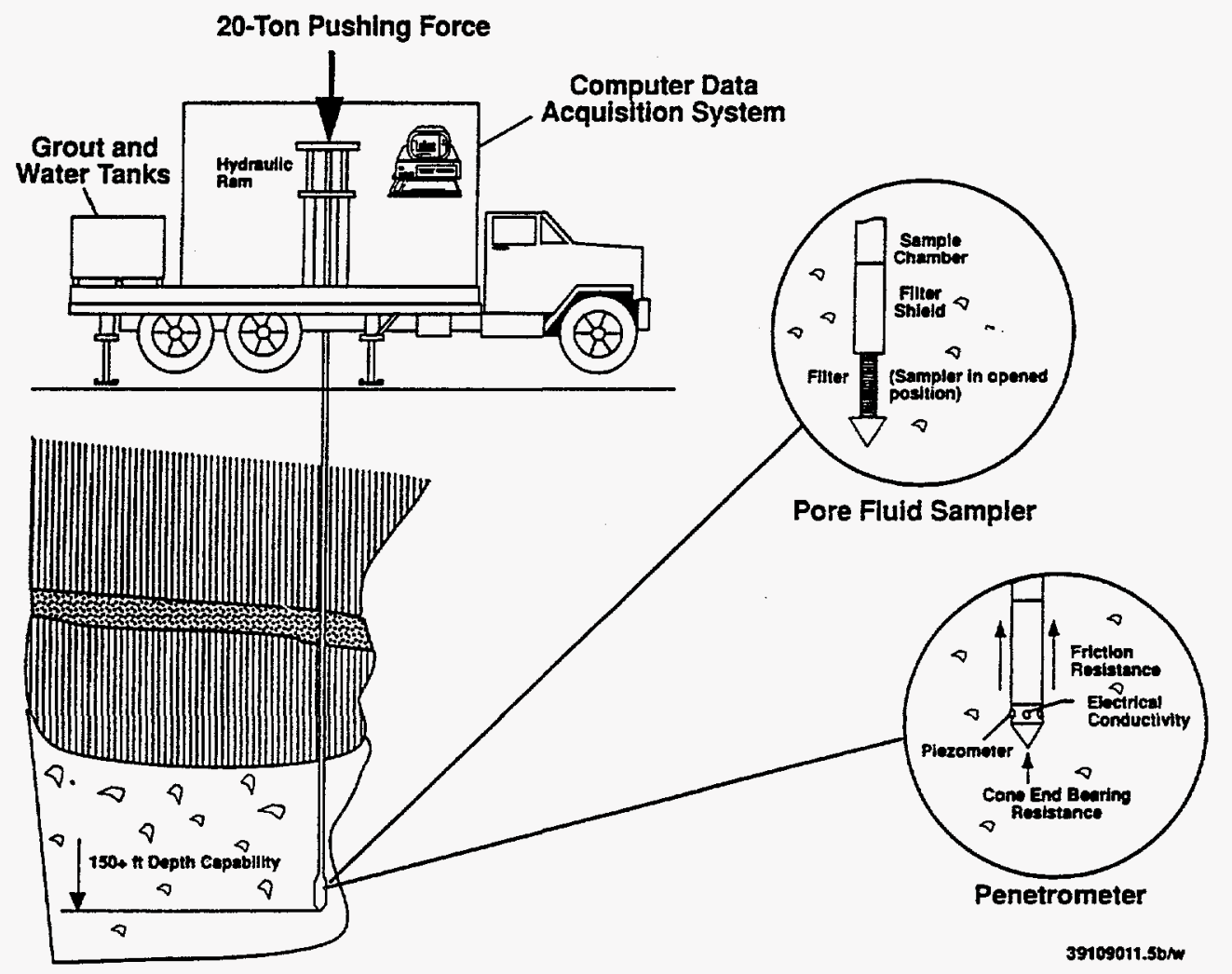

Figure 3. Schematic of a typical cone penetrometer system. (From Anderson et al., 1992)

Three groups have developed or are developing radiation probes: the U.S. Army Corps of Engineers' Waterways Experiment Station, Applied Research Associates, and Fugro, a multinational group of consulting engineers. The availability of these various types of sensors make it feasible to characterize most of the necessary matrix material parameters. At the time this information was gathered, an alpha radiation sensor had not been developed for use with the cone penetrometer; therefore, a gamma detector will have to be employed. This could lead to false negatives if there are insufficient plutonium by-products that emit gamma radiation.

The Los Alamos National Laboratory performed a cost analysis of the cone penetrometer compared to cable tool drilling and mud rotary drilling at Hanford and the Savannah River Site. In general, the cone penetrometer realized a savings of 30 to 60 percent over the drilling technologies (DOE Office of Environmental Management, 1997b). One explanation for a portion of the cost savings is a reduction in labor costs due to the speed of operation and limited manpower needed for equipment decontamination. For example, only one fully dressed-out worker was required to decontaminate the cone penetrometer equipment while four were required for a drill rig. The cone penetrometer rods are pressure steam cleaned as they are retrieved and therefore produce a minimal amount of contaminated water. Drilling operations, on the other hand, not only require decontamination of the drilling equipment but also proper treatment and disposal of drilling fluids. 
The only limitations for use of a cone penetrometer at NTS historical hydronuclear test locations are accessability, the type of material in which the test holes were placed, and requirements for sealing penetrometer holes. It is assumed that accessability (i.e., ability of a 20-to-40 ton truck to access a site) will not be an issue at most of the sites. It is probable that a heavy-weight penetrometer will be able to push through most alluvial material at the NTS, but the tests located in the indurated tuffaceous unit may be difficult to penetrate. Sealing and grouting of penetrometer holes can be performed as the cone is removed from the hole via grout ports and tubing in the penetrometer rod. Typical seal materials include bentonite slurries, neat cement, a combination of the two, or dry granular bentonite (Lutenegger and DeGroot, 1995).

Technical contacts for this technology include: Candace Rose, Argonne National Laboratory (708-252-3499); Carol Eddy Dilek, Savannah River Technology Center (803-725-2418); Neil Higgins and Jimmie Bratton, ARA (505-881-8074); Steve Lieberman and Tom Hampton, NCCOSCNRaD (619-553-2778/1172); and John Ballard, USAE Waterways Experiment Stations (601-6342446).

\section{Drilling Technologies}

Drilling is the most time consuming and costly of the characterization technologies presented in this report and therefore it is recommended only if cone penetration fails. However, drilling may be necessary to characterize the historical hydronuclear test site located in the tuffaceous unit or it may also be required if permanent monitoring wells are planned. Because drilling is extensively used for water wells and oil and gas extraction, a large amount of literature concerning these applications is available; significantly less information is available on the use of drilling for environmental characterization. There are numerous types of drilling techniques that have been developed over the years, e.g., cable-tool drilling, dry drilling, dual-air percussion drilling, ResonantSonic ${ }^{\mathrm{SM}}$ drilling, cryogenic drilling, dual-wall reverse circulation drilling, slim-hole drilling, coiled-tubing drilling, suction drilling, and the use of various drilling fluids.

The most commonly employed drilling technique at the NTS is the hollow stem auger (D. Donithan, DRI, pers. comm., 1997). Typically, this method is used for acquiring core samples and installing monitoring wells at depths less than $15 \mathrm{~m}(50 \mathrm{ft})$, although deeper depths may be achieved depending on the material present. The auger does not require drilling fluids or produce cross contamination of the soil formation. If deep holes are required or if boulders are present or the formation unit is very hard, other drilling technologies will have to be employed.

One of the primary concerns in using drilling for characterization of historical hydronuclear test areas is the potential for radioactive contamination. Of seven drilling technologies that the DOE Hanford site investigated, three were recommended for drilling in areas contaminated with hazardous and radioactive wastes (Thompson, 1993). These drilling technologies were the cable-tool method, sonic drilling and air rotary drilling. Only these technologies met most of the program criteria, i.e., reliable performance, protected samples from cross-contamination, limited radiation exposure to workers and equipment, and is a proven technology. 
The cable-tool method is a well-established method whereby the hole is drilled by repeatedly dropping and raising the drill bit. As the hole becomes deeper, the well casing is advanced until the desired depth has been reached. Thompson (1993, p. 18) states that this method "provides unaltered geologic samples, minimizes cuttings, requires nothing to be added to the cuttings to remove them from the well, and controls the spread of hazardous and radioactive contamination." The primary problem with this method is that it is significantly slower and hence more costly in comparison to

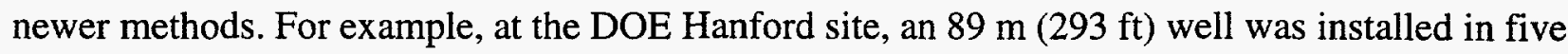
days using an air rotary drill, whereas it would have taken 30 days using the cable-tool method.

Air rotary drilling uses compressed air to power a percussion hammer and remove cuttings from the drill bit face. Because air is circulated down the center of the pipe to the hammer and returns through the annular space between the casing and the drill, there is some potential for contamination of other rock layers as well as bringing contaminated dust-laden air to the surface. While this method can realize a cost savings of 40 percent (Thompson, 1993) and a significant reduction in cuttings, it was determined to be unsuitable for areas known to be radioactively contaminated. For this reason, any drilling method that has the potential to produce airborne plutonium will not be recommended for characterization of the historical hydronuclear test areas.

Sonic or ResonantSonic ${ }^{S M}$ drilling uses a combination of mechanically generated vibrations with rotary power to force a drill bit through the soil. An oscillating drill head, consisting of two counter rotating, out-of-balance rollers, produces a resonant wave along the drill pipe which reduces the borehole wall friction on the pipe. Maximum soil penetration is achieved by a combination of pipe resonance, the weight of the pipe, and the downward thrust of the drill head. Figure 4 depicts a sonic drill rig. Continuous cores from depths as great as $167 \mathrm{~m}(550 \mathrm{ft})$ have been obtained with

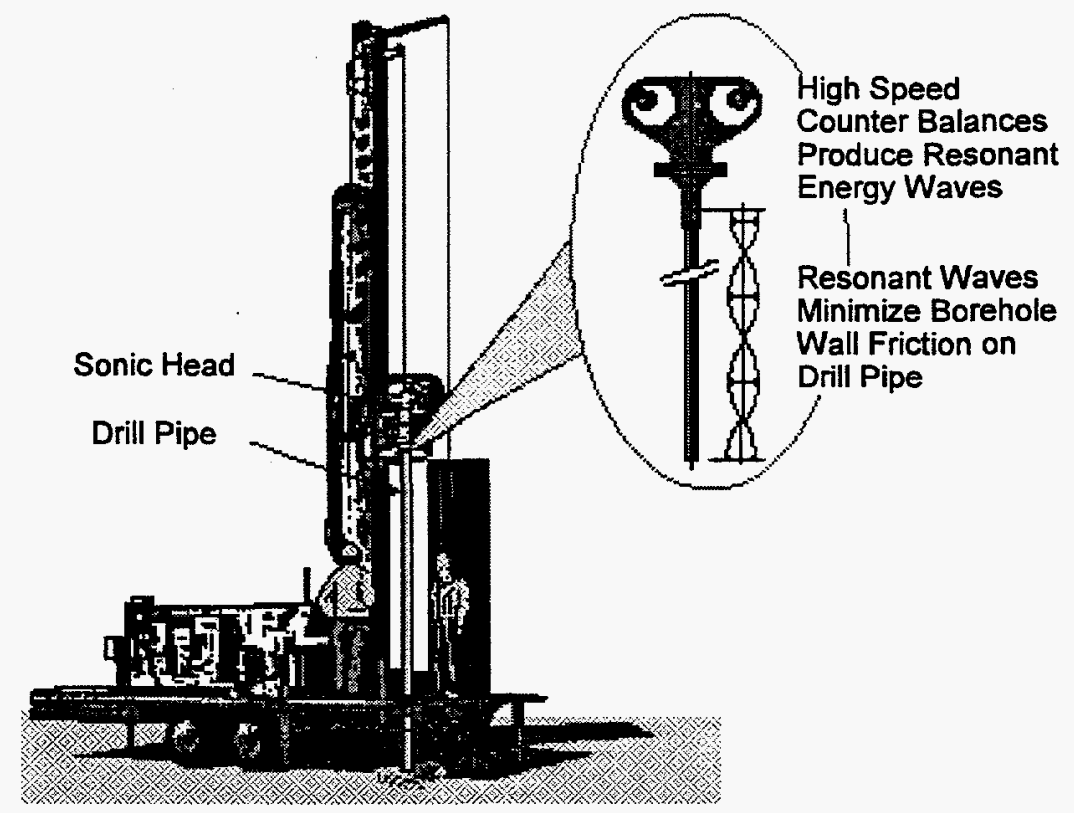

Figure 4. Schematic of a sonic drill rig and the mechanism which produces a resonant wave. (From DOE Office of Environmental Management, 1997c). 
sonic drilling. However, according to Thompson (1993), sonic drilling is most cost effective when used at depths less than $46 \mathrm{~m}$ (150 ft). The drilling rate for the sonic method ranges up to $79 \mathrm{~m} \mathrm{(260}$ $\mathrm{ft}$ ) per day. Sonic drilling has been successfully used in many geologically diverse sites, e.g., alluvium, clay-rich glacial till, and sandstone and shale units (DOE Office of Environmental Management, 1997c).

The primary advantages of using sonic drilling include: high quality, relatively undisturbed continuous cores; because no drilling fluids are used and there are no cuttings, minimal waste is generated; because minimal waste is produced, worker exposure to contaminants is limited; the method can drill slant holes as well as vertical holes; and the faster drilling rates typically result in reduced cost. The primary disadvantages of sonic drilling are the resulting microfractures in the drill pipe due to the stress produced by resonating the pipe and the heating of core materials. Under difficult drilling conditions at the DOE Hanford Site, core temperatures ranged from 21 to $60^{\circ} \mathrm{C}$ ( 70 to $140^{\circ} \mathrm{F}$ ). Generally, high core temperatures are only a problem if volatile gasses are present.

A method called rotasonic drilling was developed to address the problems of pipe microfractures and high core temperatures. Rotasonic drilling uses a core barrel attached to the drill rod as an inner casing. Resonant waves are generated to advance the core barrel until it is filled, then it is overwashed with a rotational casing using water. The outer casing holds the hole in place while the inner barrel is pulled to retrieve core. This technique puts less stress on the outer casing and maintains cooler core temperatures. However, the disadvantages include the requirement for water, which may potentially contaminate lower layers, and the additional time required to drill two holes.

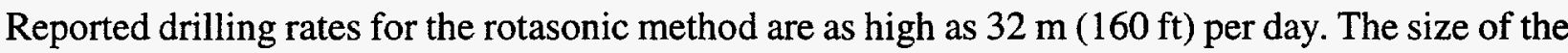
outer casing is limited to $20 \mathrm{~cm}$ ( $8 \mathrm{in}$ ) and the maximum drilling depth is currently limited to $91-122$ $\mathrm{m}(300-400 \mathrm{ft})$. As displayed in Figure 5, the cost of sonic drilling is generally less than that of cable tool despite the fact that sonic rigs cost twice as much as a standard drilling rig.

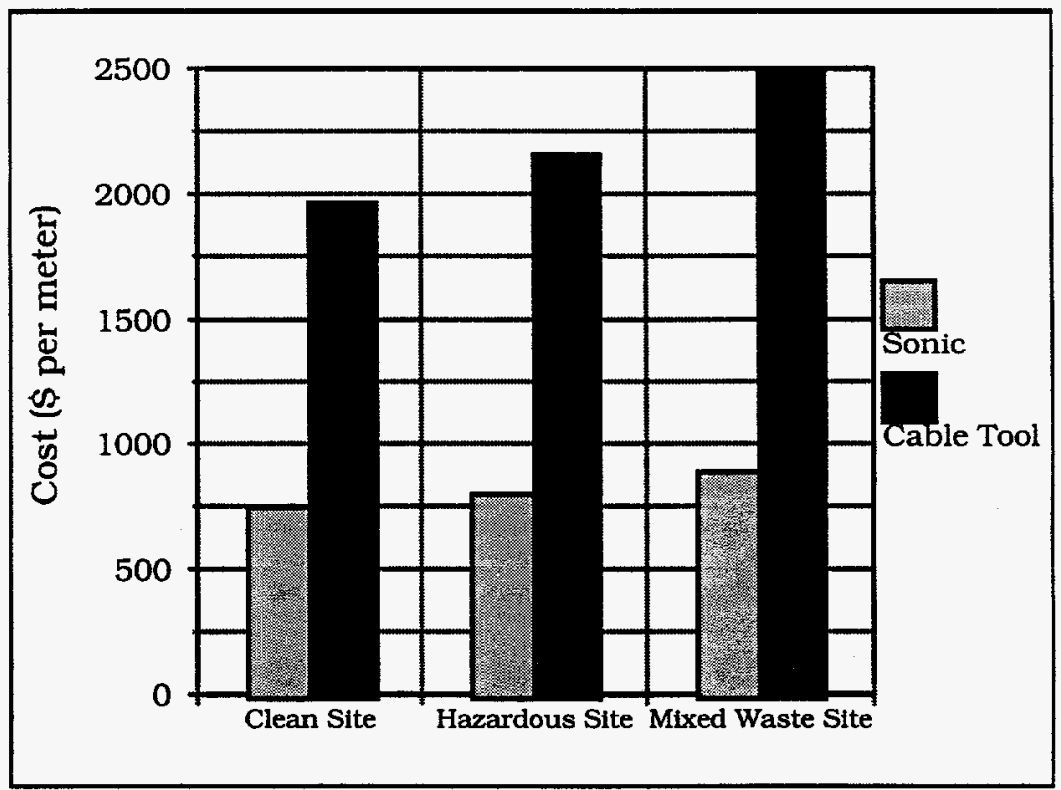

Figure 5. Comparison of drilling and completion costs for sonic and cable-tool drilling. (Extracted from DOE Office of Environmental Management Internet, 1997d) 
As a component of a public-private technology development partnership, the DOE and Water Development Corporation of California developed and demonstrated a ResonantSonic drilling rig. Demonstrations were conducted at the DOE Hanford Site, Sandia National Laboratories, the DOE Pantex Site in Amarillo, TX, the DOE Rocky Flats Site, the Idaho National Engineering Laboratory, and a number of DOD military bases and private locations. As a result of these demonstrations, a new rig with multiple drilling capabilities was designed. This rig is capable of sonic, air rotary casing hammer, cable-tool, percussion and rotary drilling. It is unlikely that this type of rig would be necessary for characterization of the historical hydronuclear test areas, but its availability is worthy of mention.

Water Development Corporation of California (WDCC) recently completed a drilling project at the NTS that was completed six weeks ahead of schedule and $\$ 100,000$ under the estimated budget (J. Barrow, WDCC, pers. comm., 1997). It was reported that the easiest and cheapest method to characterize the location of radioactive contamination would be a gamma probing technique that was developed and employed at the DOE Hanford Site. A sonic drill head was used in conjunction with a $4.5 \mathrm{~cm}$ ( $1.75 \mathrm{in}$ ) rod that contained a gamma probe. The rod was sonically pushed into the soil formation and measurements were made as the rod was pushed deeper into the soil. This technique is a quick and inexpensive way to detect the presence of gamma-emitting radiation. If sufficient plutonium is present, gamma-emitting by-products should be detectable; a detection threshold of 0.1 $\mathrm{pCi} / \mathrm{g}$ is estimated for Cs-137 (DOE Office of Environmental Management, 1997e). This technique does not produce any cuttings or transport any contamination to the surface. In fact, by extracting the rod sonically, no radioactivity was detectable on the surface of the rod after extraction (J. Barrow, WDCC, pers. comm., 1997).

Drilling methods allow two approaches to be used for characterization purposes. Analyses can be performed on the extracted cores or detectors can be lowered into the holes. Use of the extracted cores for analysis are an easy approach as samples can be sent to a laboratory for analysis based on logging results. This is the best approach for characterization of the physical and chemical properties of the soil material, however, it may be beneficial and less costly to lower a gamma detector into the hole to more thoroughly evaluate the amount of radioactive material present in the formation surrounding the test hole. Passive and neutron-induced spectral gamma-ray techniques have been developed to map contaminants in situ. The Los Alamos National Laboratory, RUST Geotech (DOE Grand Junction Projects Office), U.S. Geological Survey, Environmental Measurements Corporation (Denham, TX) and Westinghouse Hanford Company have all played a role in developing this technology. Passive spectral gamma-ray (SGR) is a very sensitive technique that positively identifies gamma-emitting contaminants, however, further development is required to make this technique quantitative. Neutron-induced spectral gamma-ray technology adds a pulsed neutron source to the SGR instrument. Because this technique is multispectral, e.g., records gamma-ray energy spectra during and after the pulsing, it can be used to positively identify many nuclides including chlorine. It is believed that SGR technology has a detection threshold of $0.1 \mathrm{pCi} / \mathrm{g}$ for Cs-137, which is an order of magnitude below background levels (DOE Office of Environmental Management, 1997e). The advantages of this technology are that it provides real-time results, in situ measurements, can be deployed with a cone penetrometer, and significantly reduces analysis costs. To prevent 
contamination of the SGR instrument, when lowered into a monitoring well, either an uncontaminated casing or a polymer membrane liner can be placed into the monitoring well. An example of the cost savings that can be realized using this technology states that full analysis of soil samples taken every $1.5 \mathrm{~m}$, from a well $61 \mathrm{~m}$ (200 ft) in depth, costs $\$ 200,000$ while the estimated cost for SGR measurement of the well is $\$ 2400$.

The technical contact for this technology include: Jeff Barrow, Water Development Corporation of California, (916)662-2829; John Conaway, Los Alamos National Laboratory, (505)667-2683; David George, RUST Geotech, (303)248-6699; and Jon Mikesell, U.S. Geological Survey, (303)236-1321.

\section{Remediation Technologies}

The characterization process will determine the location and amount of radioactive contamination, and whether the radioactive contamination is being acted upon by transport processes. Determination of a need for remediation will be based on these characterization results. If characterization shows that the plutonium from historical hydronuclear testing is amassed in a very centralized location at the bottom of the test hole, it would appear that the location of the plutonium is stable and it may be decided that no action is necessary at this time. If, however, it appears that the plutonium has moved from the immediate test hole area into the surrounding material, or that the geohydrology of the area may result in contaminant movement, remediation will be warranted. Currently, it is not known how far the plutonium was disseminated into the surrounding material during detonation, however, some information on this may be available from measurements that were collected as a component of the test. The reports that contain this information should be available in the near future. Because it is believed that most of the test holes range in depth from 15 to $49 \mathrm{~m}$ (50-160 ft), excavation is not a cost-effective remediation option. In addition, given the environmental and health physics concerns regarding remediation associated with the historical hydronuclear experiments, non-intrusive methods of stabilization/solidification are strongly preferred if remediation is necessary. Therefore, this report will only examine in situ remediation technologies, specifically, capping or sealing the surface, in situ grouting, and in situ vitrification.

\section{Surface Capping or Sealing}

The utilization of surface caps or seals has been well developed for landfill applications. Typically, low permeability clays such as kaolinite or bentonite have been used as compacted soil layers (CSLs). However, compacted clay barriers are not only expensive, they are not suited to arid conditions in which hydrologic failure would be expected. Failure of surface caps are typically the result of crack formation from wetting and drying cycles of CSLs (Phifer $e$ t al., 1995). Clays swell and expand when wet, but drying causes shrinkage and sometimes cracks will form. If the cracks are deep enough, infiltration into the subsurface will occur. Various repair technologies have been developed to close cracks that have formed in surface caps. These repair techniques include the application and recompaction of new kaolinite, covering the crack with a bentonite geosynthetic clay liner, or injection of colloidal silica or polysiloxane directly into the crack (Persoff et al., 1997). 
Alternative cover designs, such as evapotranspiration (ET) (Anderson, 1997) or capillary barrier (Dwyer, 1997) covers, are being developed for arid conditions. These covers utilize the natural aridity to prevent infiltration from exiting the cover. An ET cover uses the ET processes of native vegetation to remove the infiltrated water by providing a surface material that has sufficient water storage capacity to hold the water until the venation can remove it. A capillary barrier cover uses a similar concept but provides additional protection by including a layer of dramatically coarsergrained material below the root zone material, which prevents infiltrated water from draining from the root zone under unsaturated conditions. Both cover designs are substantially less expensive than a CSL cover (Dwyer, 1997) and are expected to not only out-perform a CSL cover under arid conditions, but to have longer term viability. If a fire or other form of vegetation-removal occurs, however, an ET cap may fail.

Other techniques for forming a hydrologic surface barrier include injectable barrier liquids such as colloidal silica, polybutenes or polysiloxane. These barrier liquids are generally chemically and biologically inert, hydrophobic and impermeable to water. Their containment performance is dependent upon temperature and in the case of colloidal silica, the $\mathrm{pH}$ and chemistry of the soil and waste. The primary function of a surface cap is to prevent infiltration of precipitation or runoff into the soil layers beneath the cap, and a thin impermeable surface layer that accomplishes this objective may be possible by applying one of these liquids to the surface.

Whether or not transport of the radioactive materials associated with historical hydronuclear testing has occurred, it is recommended that a surface cap or seal be placed over the test holes to protect against channelization of water directly down the test hole. The potential for relatively rapid transport of contaminants via channelized water is one of the largest risks associated with these sites other than human intervention. The establishment of a cap is very inexpensive in comparison to the remediation technologies that would have to be employed if the radioactive contaminants are leached into the groundwater.

\section{In Situ Grouting}

In situ grouting is a remediation approach that places an impermeable barrier beneath an existing waste site without excavation. There are two emplacement technologies that may be employed, permeation and jet grouting. Permeation grouting used low pressure to inject a low viscosity grout into the soil with minimum disturbance; filling soil pores without significantly altering soil structure. Jet grouting uses high pressures to inject grout into the soil and therefore the soil structure is completely altered, i.e., soil and grout become thoroughly mixed. In either case, it is likely that a cone penetrometer or boreholes can be used as a delivery system for the grout. The use of vertical boreholes and penetrometers to deliver grout beneath the radioactive contamination may require some pilot testing before reliability of grout placement can be ensured.

DOE, Halliburton NUS, and the University of Cincinnati are collaborating to develop and test the use of parallel, curved drill holes for efficient delivery and placement of in situ grout. The drill holes curve down from the surface under the waste and back up to the surface on the other side. What is attractive about this technique is the ability to ensure that grout is placed directly beneath the waste. There is some uncertainty involved with other techniques that use penetrating systems or 
boreholes that are completely vertical and must therefore rely upon horizontal flow of the grout for placement. Currently, the developers of this technology have only experimented with shallow wastes, e.g., $3.6 \mathrm{~m}$ (12 ft) (DOE Office of Environmental Management, 1997f). While this technology would not be appropriate for deep borehole remediation, it might be a potential remediation technology for other historical hydronuclear test areas that do not employ deep boreholes. Contacts for this technology include: David Ridenour of FERMCO, Cincinnati, OH (513-648-6138); Dr. Paul Pettit of FERMCO, Cincinnati, OH (513-648-6558); and Jaffer Mohiuddin, DOE, Germantown, MD (301903-7965).

Several types of grouts have been developed or are being tested for in situ remediation. The list of grouts include: clay-based grouts, hydraulic cements, sulfur polymer cement, vinylester styrene, polyester styrene, furfuryl alcohol, high molecular weight acrylic, a mineral wax/bentonite emulsion called monton wax, a glyoxal-modified sodium silicate grout, and colloidal silica (DOE, Office of Environmental Management Internet web site). The selection of an appropriate grout is dependent on the soil material, geohydrologic environment, and the contaminant type. Several of the above listed grouts were specifically developed to act as a barrier to hazardous waste and therefore are designed to be chemically inert. For remediation of historical hydronuclear test areas, the primary requirements are an ability to remain impermeable in a radioactive environment, nonreactive with water, and cost effective.

Portland cement grouts have been noted to crack due to the shrinkage and thermal stresses induced by hydration reactions (DOE Office of Environmental Management, 1997g) and therefore are not reliable for use in remediating historical hydronuclear test areas. DOE, specifically Sandia National Laboratories, Brookhaven National Laboratory and Lawrence Berkeley Laboratory, has collaborated with private industry to develop and test the grouts previously listed. The montan wax and glyoxal-modified sodium silicate grouts were evaluated by the Sandia National Laboratories. The results indicate that these grouts are capable of laterally penetrating unconsolidated soils to provide a horizontal barrier to contaminate transport. This was performed by using an array of boreholes around the buried waste to inject the grout. Additional information about the evaluation and grout costs were not available at the time this report was written. Information regarding these grouts may be obtained by contacting: Rudolph Matalucci at Sandia National Laboratories (505-8448804); Charles Voss with Golder Associates, Inc., Redmond, WA (206-883-0777); and George Allen at Sandia National Laboratories (505-844-9769).

The use of colloidal silica as a subsurface grout was evaluated by the Lawrence Berkeley Laboratory (LBL). Colloidal silica can be made into a gelatinous grout by adding brine, then injecting it into the soil. After gelling, the colloidal silica fills the pore spaces and acts as a barrier. The evaluation that was performed by LBL mixed colloidal silica (DuPont Ludox SM) with a silica sand and brines made from water and sodium chloride and poured into cylindrical molds. Several experiments were performed on the sand and grout cylinders to test hydraulic conductivity, compressive strength and resistance to chemical contaminants. The results show that for a silica particle concentration of greater than 7.4 percent by weight yielded a hydraulic conductivity of less than $1.0 \times 10^{-7} \mathrm{~cm} / \mathrm{s}$, which is an acceptable value for contaminant barriers. The evaluation also showed that samples immersed in water gained strength for 95 days (Persoff et al., 1996). Further 
evaluation is necessary to determine the ability of this grout to flow laterally to form a barrier beneath subsurface contamination, but the initial results appear promising. The researchers for this effort are at LBL (510-486-4746) Peter Persoff, John Apps and George Moridis, or Joyce Whang (609-540-4275) at DuPont Central Research and Development, Deepwater, NJ.

The remaining grouts listed above, e.g., sulfur polymer cement, vinylester styrene, polyester styrene, furfuryl alcohol, and high molecular weight acrylic, are being evaluated by the Brookhaven National Laboratory. At this time, no results were available. The contacts at Brookhaven are Dr. John Heiser (516-344-4405) and Eena-Mai Franz (516-344-7103).

\section{In Situ Vitrification}

In situ vitrification is a thermal technology that can be used to chemically alter and immobilize contaminants in place. This technology was originally developed by the Pacific Northwest Laboratories Division of Battelle Memorial Institute, Richland, WA (Shearer, 1991). A spin-off company from the initial vitrification research effort, Geosafe Corporation, now commercially employs vitrification technology for contaminant remediation.

Vitrification typically involves the use of electrodes placed in the soil to directly heat and vitrify soils at temperatures between $1400^{\circ}$ and $2000^{\circ} \mathrm{C}\left(2552^{\circ}\right.$ and $\left.3632^{\circ} \mathrm{F}\right)$ as depicted in Figure 6 (McAdams, 1993). The soil must not be saturated above the vitrification zone as the heat will volatilize water into gas, and if the gas cannot permeate through the soil very rapidly, an explosion will occur. This has been referred to as "the big burp" and can lead to release of hazardous or radioactive contaminants. Because the vadose zone is thick and composed of coarse-grained materials at the NTS, it is highly improbable that an explosion would occur. Shearer (1991) states that the cost for in situ vitrification ranges from $\$ 275$ to $\$ 600$ per ton of soil depending on the volume of material to be processed, accessibility and cost of electricity, and the soil moisture content.

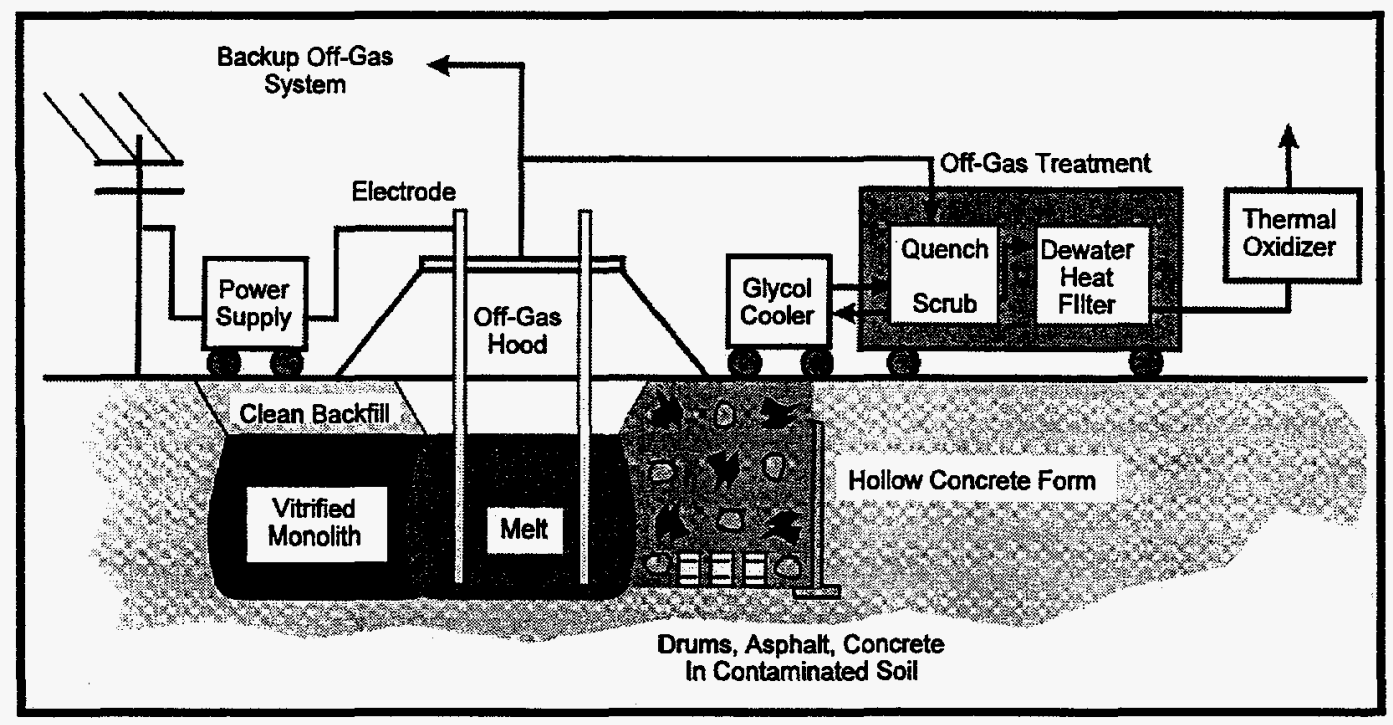

Figure 6. An illustration of the Geosafe large-scale in situ vitrification system (Taken from a Geosafe brochure). 
One of the limitations of vitrification technology for remediation of the NTS historical

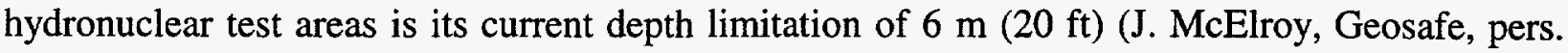
comm., 1997). Geosafe has been successfully using vitrification to immobilize near-surface plutonium from nuclear tests performed by the United Kingdom in Australia. McElroy stated that grouting and subsurface barriers do not work well and vitrification is the only fully reliable technique for immobilizing radioactive contamination. While there is currently no vitrification unit capable of vitrifying soils at depths of $27 \mathrm{~m}$ (90 ft) or more, with some research and development, the Geosafe unit can be re-engineered, and there is no reason that vitrification could not be used at deep depths (J. McElroy, Geosafe, pers. comm., 1997).

\section{CONCLUSIONS AND RECOMMENDATIONS}

This report discussed several technologies that might be employed to characterize and, if necessary, remediate historical hydronuclear test areas at the Nevada Test Site. The characterization technologies examined included the Pipe Explorer ${ }^{\mathrm{TM}}$, cone penetrometers and various drilling technologies. The Pipe Explorer ${ }^{\mathrm{TM}}$ would use the existing boreholes to provide access for probes to measure the amount and location of radioactive contamination. Cone penetrometers would push sensors into the soil to measure radioactivity and various soil properties. Drilling techniques require the removal of soil material to provide borehole access to sensors, although the resonant sonic drilling technique does not remove soil material or require drilling fluids and therefore virtually eliminates the potential for cross-contamination. A thorough cost comparison of these technologies has not been conducted at this time, but it is believed that either the use of existing drilling equipment at the NTS or the Pipe Explorer ${ }^{\mathrm{TM}}$ would likely be the most cost-effective technique to assess the level of radioactive contamination.

If remediation is required, a combination of surface capping and subsurface grouting may be the most cost-effective techniques available. If there is a high risk of groundwater contamination, it may be critical and appropriate to invest funds into the research and redesign of in situ vitrification systems to enable vitrification at depths greater than $6 \mathrm{~m}$.

Due to the limited knowledge of the nature the historical hydronuclear tests and their hydrologic setting, it is difficult to make specific recommendations for appropriate characterization and remediation technologies. When it becomes possible to review the existing documentation on the NTS historical hydronuclear tests and visit the sites, more specific recommendations may be made. 


\section{CITATIONS AND OTHER REFERENCES}

\section{Pipe Explore ${ }^{\mathrm{TM}}$ Technology}

Cremer, C.D., W. Lowry, E. Cramer and D.T. Kendrick, 1995. Characterization of Radioactive Contamination Inside Pipes with the Pipe Explorer ${ }^{\mathrm{TM}}$ System, Proceedings of the Environmental Technology through Industry Partnership Conference, U.S. Department of Energy, Morgantown Technology Center, Morgantown, W. Va.

Kendrick, D.T. and C.D. Cremer, 1996. Pipe Explorer ${ }^{\mathrm{TM}}$ : Overview, applications, and recent developments. Preprint from Spectrum '96, International Topical Meeting on Nuclear and Hazardous Waste Management, August 18-23, 8 p.

Kendrick, D.T., C.D. Cremer, W. Lowry and E. Cramer, 1995. Alpha Detection in Pipes using an Inverting Membrane Scintillator, Proceedings of the Environmental Technology through Industry Partnership Conference, U.S. Department of Energy, Morgantown Technology Center, Morgantown, WV.

McCown, Andy, 1996. Pipe Explorer ${ }^{\mathrm{TM}}$, Los Alamos National Laboratory Technology and Safety Assessment Division, Energy and Environmental Analysis Group, Los Alamos, NM.

\section{Cone Penetrometer Technology}

Advanced Sciences, Inc., 1994. Review of Instrumentation and Sensors Cone Penetrometer Applications Task 6 Report, DOE/HWP-149.

Anderson, D.B., J.N. Hartley, S.P. Luttrell and R.E. Hinchee, 1992. Innovative Technology Demonstrations. Proceedings ASFA 3: Aquatic Pollution \& Environmental Section: Q5 08502 Methods \& Instruments, PNL-SA-20750, pp. 309-315.

Booth, S.R., C.J. Durepo and D.L. Temet, 1993. Cost Effectiveness of the Cone Penetrometer Technology, Los Alamos National Laboratory Report, LA-UR-93-3383.

Cespedes, E.R., S.R. Cooper and W.M. Davis, 1994. In Situ Detection of TNT Contamination using Electrochemical Sensors in Cone Penetrometer System, Optical Sensors for Environmental and Chemical Process Monitoring, Proceedings of Society of Photo-Optical Instrumentation Engineers, McLean, VA, Nov. 9-10, v.2367, pp. 33-42.

Knowlton, R., W. Strong, J. Onsurez and E. Rogoff, 1995. Advances in Hydrologic Measurement Techniques--In-Situ and Cone Penetrometer Applications, SPIE Volume 2504, Environmental Monitoring and Hazardous Waste Site Remediation, Proceedings Europt Series, Munich FRG, June 1995.

Kyle, K., 1994. Conceptual Design of a Raman Probe for Inclusion in the In-tank Cone Penetrometer, Lawrence Livermore National Laboratory Report, UCRL-ID-118926.

Lutenegger, A.J. and D.J. DeGroot, 1995. Techniques for sealing cone penetrometer holes. Canadian Geotechnical Journal, 32:880-891. 
Richterich, L.R. and B.R. Cassem, 1994. Cone Penetrometer Testing at the Hanford Site: Final Performance Evaluation Report, Westinghouse Hanford Company Report WHC-EP-0797.

Schroeder, J.D., S.R. Booth and L.K. Trocki, 1991. Cost Effectiveness of the Site Characterization and Analysis Penetrometer System, Los Alamos National Laboratory Report, LA-UR-91-4016.

Smolley, M. and J.C. Kappmeyer, 1991. Cone penetrometer tests and HydroPunch ${ }^{\circledR}$ sampling: A screening technique for plume definition. Groundwater Monitoring Review, 11:101-106.

Steedman, D., F. Seusy, J. Gibbons and J. Bratton, 1993. Minimally Invasive Three-dimensional Site Characterization System, Argonne National Laboratory Report DOE/CH-9202.

Stromswold, D.C., J.E. Meisner and W.G. Nicaise, 1994. CsI(Tl) with Photodiodes for Identifying Subsurface Radionuclide Contamination, Pacific Northwest Laboratory Report PNL-SA-24344.

Treen, C.R., P.K. Robertson and D.J. Woeller, 1992. Cone penetration testing in stiff glacial soils using a down hole cone penetrometer. Canadian Geotechnical Journal, 29(3):448.

\section{Drilling Technology}

Barrow, J.C., 1994. The resonant sonic drilling method: An innovative technology for environmental restoration programs. Ground Water Monit. Rem., 14(2):153-160.

Burnham, J., J. Conaway, J. Duray, S. Frankle, D. George, J. Mikesell, P. Nelson and R. Wilson, 1994. Contaminant Detection Thresholds for the Multispectral Neutron Borehole Logging Method: Preliminary Report, J. Conaway and J. Duray, eds., DOE/ID/12584-188, 21 p.

Cohen, J.H, W.C. Maurer and E.C. Leitko, 1995. High-power slim-hole drilling system. The 1995 SPE Annual Technical Conference and Exhibition, Dallas, TX, USA, 10/22-25/95, Proc SPE Ann. Tech. Conf. Exhib., Society of Petroleum Engineers (SPE), Richardson, TX, vol. Delta, pp. 371-376.

Conaway, J.G. and J.R. Hearst, 1993. Mapping Contaminants with Nuclear Borehole Logging Techniques, Los Alamos National Laboratory, Los Alamos, NM, LA-UR 93-1915, 13 p.

De Souza, EM, 1992. Dry drilling in underground production. Cim Bull., 85(963):6-50.

Gary, S.C. and D.M. Doremus, 1995. Technical and economical feasibility of coiled tubing drilling. The 1995 SPE Annual Technical Conference and Exhibition, Dallas, TX, USA, 10/22-25/95, Proc SPE Ann. Tech .Conf. Exhib., Society of Petroleum Engineers (SPE), Richardson, TX, vol. Delta, pp. 405-413.

Hearst, J.R., 1994. Choice of Computer Software for Analysis of Spectra from the Multispectral Logging System, University of California Radiation Laboratory, UCRL-ID-118023, 7 p.

Hearst, J.R, J.R. Brodeur, C.J. Koizumi, J.G. Conaway, J.L. Mikesell, P.H. Nelson, D.C. Stromswold and R.D. Wilson, 1993. DOE Capabilities for In Situ Characterization and Monitoring of Formation Properties in the Vadose Zone, University of California Radiation Laboratory, UCRL-JC-113790, 15 p. 
Holsten, D.B. and J. Morgan, 1989. The Dual-Tube Air Percussion Drilling Method for Installation of Groundwater Monitoring Wells. IN: Proceedings of the Third National Outdoor Action Conference on Aquifer Restoration, Ground Water Monitoring and Geophysical Methods. National Water Well Association, Dublin, OH, pp. 1-13.

Long, R., D. Wonderly and E. Wright, 1991. Dry drilling and coring development for unsaturated zone studies. Yucca Mountain Site Characterization Project, Las Vegas, NV, The 2nd Annual International Conference on High Level Radioactive Waste Management, Las Vegas, NV, 04/28-05/03/91, High Level Radioactive Waste Management, ASCE, New York, NY, pp.810-815.

Masten, D. and S. Booth, 1995. Cost-Effectiveness Study of Sonic Drilling, Los Alamos National Laboratory Report, preprint.

Persson, L. and L. Bergstrom, 1991. Drilling method for collection of undisturbed soil monoliths. Soil Science Society of America Journal, 55(1):285.

Reid, P.I., G.P. Elliott, R.C. Minton, B.D. Chambers and D.A. Burt, 1993. Reduced environmental impact and improved drilling performance with water-based muds containing glycols. The SPE/EPA Exploration and Production Environmental Conference, San Antonio, TX, USA, 03/07-10/93, Proc. SPE EPA Explore Prod. Environ. Conf., Society of Petroleum Engineers, P.O. BOX 833836, Richardson, TX, pp. 453-463.

Russell, DL, 1996. Using horizontal wells as a remediation tool. Environmental Protection, 7(1):36.

Russell, B.F., J.M. Hubbell and S.C. Minkin, 1989. Drilling and Sampling Procedures to Minimize Borehole Cross-Contamination. IN: Proceedings of the Third National Outdoor Action Conference on Aquifer Restoration, Ground Water Monitoring and Geophysical Methods. National Water Well Association, Dublin, OH, pp. 81-93.

Shirley, D.H. and S.M. Hay, 1988. Using the Percussion Hammer Drill to Install Groundwater Monitor Wells in Coarse Alluvial Deposits. IN: Proceedings of the Second National Outdoor Action Conference on Aquifer Restoration, Ground Water Monitoring and Geophysical Methods. Volume I. National Water Well Association, Dublin, OH, pp. 289-302.

Simon, R.D. and G.A. Cooper, 1996. Cryogenic drilling: A new drilling method for environmental remediation. Ground Water Monit. Rem., 16(3):79-85.

Simon, R.D. and G.A. Cooper, 1994. Use of cryogenic fluids for environmental drilling in unconsolidated formations. The Energy-Sources Technology Conference, New Orleans, LA, USA, 01/23-26/94, ASME Pet. Div. Publ. Pd., ASME, New York, NY, vol. 56, pp. 199-205.

Teasdale, W.E. and R.R. Pemberton, 1990. Experimental Suction Drilling in Basalts at the Idaho National Engineering Laboratory, ID, available from Books and Open Files Reports Section, USGS Box 25425, Denver, CO 80225. USGS Water-Resources Investigations Report 90-4206, $10 \mathrm{p}$. 
Thompson, KM, 1993. GAO Recommends Efficient Drilling Methods. Water Environment \& Technology, 5(7):16,18-19.

Vogel, A., 1990. Use of Specialized Mining and Petroleum Drilling Technology for Environmental Applications. IN: Superfund ' 90 . Proceedings of the 11 th National Conference, November 26-28, 1990, pp. 409-414.

Whitfield, M.S., W. Thordarson, D.P. Hammermeister and J.B. Warner, 1990. Drilling and Geohydrologic Data for Test Hole USW UZ-1, Yucca Mountain, Nye County, Nevada. U.S. Geological Survey, Box 25425, Federal Center, Denver, CO 80225. Open-File Report 90-354, $40 \mathrm{p}$.

Wilson, D.D., 1995. Federally funded innovative drilling demonstrations. Water Well J., 49(1):54-55.

Wilson, D.D., 1995. Innovative drilling demonstrations - beware, be smart! Water Well J., 49(5):48-50.

\section{Remediation}

Anderson, J., 1997. Soil-plant cover systems for final closure of solid waste landfills in arid regions. Landfill Capping in the Semi-Arid West: Problems, Perspectives, and Solutions. (Eds) T.D. Reynolds and R.C. Morris. May 1997, Environ. Sci. and Res. Foundation, Idaho Falls, ID, pp. 27-38.

Anderson, D.B., S.P. Luttrell, J.N. Hartley and R. Hinchee, 1992. Innovative technology demonstrations, Battelle Pac. Northwest Labs., 10 p. PNL-SA-20750, CONF-920851-80.

Anon, 1994. Remediation technology comparison compiled by EPA and the U.S. Air Force, Hazard. Waste Consult., 12(2):1.1-1.11.

Arnould, M., C. Clement and D. Gouvenot, 1991. New sorbing grouts for radioactive and toxic heavy metals. Engineering Geology, 30(1):127.

Cabrera-Guzman, D., J.T. Swartzbaugh and A.W. Weisman, 1990. Use of electrokinetics for hazardous waste site remediation, J. Air Waste Management Assoc., 40:1670-1676.

Conca, J.L. and J. Wright, 1992. Diffusion and flow in gravel, soil, and whole rock. Applied Hydrogeology, 1:5-24.

Devgun, J.S., I.O. Sewell and J. DeGregory, 1995. Developing innovative environmental technologies for DOE needs, Conference: The 1995 30th Intersociety Energy Conversion Engineering Conference, IECEC, Orlando, FL, USA, Proc. Intersoc. Energy Convers. Eng. Conf., 1995, vol. 2, pp. 49-54.

DOE Office of Environmental Management, 1997a. Internet web site: www.em.doe.gov/plumesfa/intech/pipeesp/perf.html

DOE Office of Environmental Management, 1997b. Internet web site: www.em.doe.gov/cgi-bin/parse/plumesfa/intech/conepen/cost.html 
DOE Office of Environmental Management, 1997c. Internet web site: www.em.doe.gov/plumesfa/intech/rsd/sum.html

DOE Office of Environmental Management, 1997d. Internet web site: www.em.doe.gov/plumesfa/intech/rsd/cost.html

DOE Office of Environmental Management, 1997e. Internet web site: www.em.doe.gov/raincmst/cmst19.html

DOE Office of Environmental Management, 1997f. Internet web site: www.em.doe.gov/rainland/land411.html

DOE Office of Environmental Management, 1997g. Internet web site: www.em.doe.gov/rainland/land412.html

Dwyer, S.F., 1997. Large-scale field study of landfill covers at Sandia National Laboratories. Landfill Capping in the Semi-Arid West: Problems, Perspectives, and Solutions. (Eds) T.D. Reynolds and R.C. Morris. May 1997, Environ. Sci. and Res. Foundation, Idaho Falls, ID. pp. 87-107.

Environmental Protection Agency, Off. of Research and Development, 1993. The Superfund Innovative Technology Evaluation Program. Annual Report to Congress 1993, EPA, Washington, D.C., Report No. EPA/540/R-94/518.

Feintuch, H.M., 1990. Demonstration Results for Three Innovative Technologies, IN: Innovative Hazardous Waste Treatment Technology Series. Volume 2: Physical/Chemical Processes. Technomic Publishing Co., Inc., Lancaster, PA, pp. 101-110.

Floess, C.H., R.F.J. Smith and R.H. Hitchcook, 1995. Capping with fiber clay. Civil Engineering, 65(8):62.

Huang, F.H., D.E. Mitchell and J.M. Conner, 1994. Low-level radioactive Hanford wastes immobilized by cement based grouts. Nuclear Technology, 107(3):254.

Kovalick, W.W., 1992. Trends in Innovative Treatment Technologies at Contaminated Sites, Water Science and Technology WSTED4, 26(1-2):99-106.

Kovalick, W.W., J. Kingscott and D. Sullivan, 1990. Selecting Innovative Treatment Technologies: A Practitioner's Guide, IN: Superfund '90. Proceedings of the 11th National Conference, November 26-28, 1990. pp. 716-719.

McAdams, C.L., 1993. Technologies for soil remediation, Waste Age., 24(5):37-44.

Oak Ridge National Laboratory (ORNL), 1996. Technical Evaluation Summary of the In Situ Vitrification Melt Expulsion at the Oak Ridge National Laboratory on April 21, 1996. ORNL/ER-374, 51 p.

Onofrei, M., M.N. Gray and W.E. Coons, 1992. High performance cement-based grouts for use in a nuclear waste disposal facility. Waste Management, 12(2/3):133. 
Persoff, P., J. Apps, G. Moridis and J. Whang, 1996. Effect of dilution of colloidal silica on strength and hydraulic conductivity of grouted sand and soil. Presented at International Containment Technology Conference and Exhibition, St. Petersburg, FL, Feb 9-12, 1997. Preprint, Lawrence Berkeley National Laboratory (LBNL-39347), 7 p.

Persoff, P., G. Moridis, D.M. Tuck and M.A. Phifer, 1997. Laboratory testing of closure cap repair techniques. International Containment Technology Conference and Exhibition, St. Petersburg, FL, Feb 9-12. Preprint, Lawrence Berkeley National Laboratory (LBNL-39324), 8 p.

Phifer, M.A., D. Boles, E.C. Drumm and G.V. Wilson, 1995. Comparative response of two barrier soils to post compaction water content variations. ASCE Specialty Conference: Geoenvironment 2000: Characterization, Containment, Remediation, and Performance in Environmental Geotechnics. Feb 22-24, 1995, pp. 519-607.

Powell, DM., 1994. Selecting innovative cleanup technologies: EPA resources. Chem. Eng. Prog., 90(5):33-41.

Ritter, J.A., J.R. Zamecnik, N.D. Hutson, M.E. Smith and J.T. Carter, 1992. High-level radioactive waste vitrification technology and its applicability to industrial waste sludges. Water Science Technology, 25(3):269-271.

Shearer, T.L., 1991. A comparison of in situ vitrification and rotary kiln incineration for soils treatment. J. Air Waste Management Assoc., 41(9):1259-1264.

Valkenburg, N. 1994. The evolution of groundwater remediation strategies, Geraghty \& Miller, Inc. Plainview, NY, Natl. Environ. J., 4(4):42-45. 


\section{DISTRIBUTION}

Bob Bangerter

Environmental Restoration Division

Nevada Operations Office

U.S. Department of Energy

P.O. Box 98518

Las Vegas, NV 89193-8518

Joanne M. Bradbery, Director

Contract Management Division

Nevada Operations Office

U.S. Department of Energy

P.O. Box 98518

Las Vegas, NV 89193-8518

David Bedsun

Defense Special Weapons Agency

Field Command

Nevada Operations Office

P.O. Box 208

Mercury, NV 89023-0208

Mary Lou Brown

International Technology Corporation

4330 S. Valley View

Suite 114

Las Vegas, NV 89103

James Cebe

Energy Technologies Division

Nevada Operations Office

U.S. Department of Energy

P.O. Box 98518

Las Vegas, NV 89193-8518

Beverly Colbert

Contract Management Division

Nevada Operations Office

U.S. Department of Energy

P.O. Box 98518

Las Vegas, NV 89193-8518

Frank Di Sanza, Director

Energy Technologies Division

Nevada Operations Office

U.S. Department of Energy

P.O. Box 98518

Las Vegas, NV 89193-8518
Brian Dozier

Bechtel Nevada Corporation

P.O. Box 98521

Las Vegas, NV 89193-8521

Doug Duncan

Hydrology Program Manager

Environmental Protection Division

Nevada Operations Office

U.S. Department of Energy

P.O. Box 98518

Las Vegas, NV 89193-8518

Dennis Farmer

Radiation Sciences Laboratory

Office of Radiation and Indoor Air

U.S. Environmental Protection Agency

P.O. Box 98517 , M/S 513

Las Vegas, NV 89193-8517

Larry Franks

Nevada State Health Department

Radiological Health Section

620 Belrose Avenue

Las Vegas, NV 89158

Joseph M. Ginanni

Waste Management Division

Nevada Operations Office

U.S. Department of Energy

P.O. Box 98518

Las Vegas, NV 89193-8518

Kenneth Hoar, Director

Environmental Protection Division

Nevada Operations Office

U.S. Department of Energy

P.O. Box 98518

Las Vegas, NV 89193-8518

Kathy Izell

Assistant Manager for Technical Services

Nevada Operations Office

U.S. Department of Energy

P.O. Box 98518

Las Vegas, NV 89193-8518 
Roger Jacobson

Desert Research Institute

Water Resources Center

P.O. Box 19040

Las Vegas, NV 89132-0040

Marjory Jones

Desert Research Institute

Water Resources Center

P.O. Box 60220

Reno, NV 89506-0220

Jim Kannard

Bechtel Nevada Corporation

P.O. Box 98521

Las Vegas, NV 89193-8521

Randy Laczniak

U.S. Geological Survey

Water Resources Division

6770 S. Paradise Rd.

Las Vegas, NV 89119

Steve Lawrence

Engineering and Asset Management Division

Nevada Operations Office

U.S. Department of Energy

P.O. Box 98518

Las Vegas, NV 89193-8518

Steve Leedom

Stockpile Stewardship Division

Nevada Operations Office

U.S. Department of Energy

P.O. Box 98518

Las Vegas, NV 89193-8518

Charles E. McWilliam, Director

Defense Projects Division

Nevada Operations Office

U.S. Department of Energy

P.O. Box 98518

Las Vegas, NV 89193-8518
Steve Mellington, Director

Environmental Restoration Division

Nevada Operations Office

U.S. Department of Energy

P.O. Box 98518

Las Vegas, NV 89193-8518

Leslie A. Monroe

Environmental Protection Division

Nevada Operations Office

U.S. Department of Energy

P.O. Box 98518

Las Vegas, NV 89193-8518

Colleen O'Laughlin

Energy Technologies Division

Nevada Operations Office

U.S. Department of Energy

P.O. Box 98518

Las Vegas, NV 89193-8518

Ken Rehfeldt

Geotrans, c/o IT

4330 Valley View

Suite 112, MS-439

Las Vegas, NV 89103

Stuart E. Rawlinson

Bechtel Nevada Corporation

P.O. Box 95487 , M/S 580

Las Vegas, NV 89193-5487

Monica Salazar-Sanchez

Environmental Restoration Division

Nevada Operations Office

U.S. Department of Energy

P.O. Box 98518

Las Vegas, NV 89193-8518

Ralph Smiecinski

Energy Technologies Division

Nevada Operations Office

U.S. Department of Energy

P.O. Box 98518

Las Vegas, NV 89193-8518

David K. Smith

Isotopes Sciences Division

Lawrence Livermore National Laboratory

P.O. Box 808, M/S L231

Livermore, CA 94550 
Michael J. Sully

Bechtel Nevada

P.O. Box 98521, M/S 966

Las Vegas, NV 98193-8521

Joe Thompson

Los Alamos National Laboratory

INC-11, MS J514

P.O. Box 1663

Los Alamos, NM 87545

Doug Trudeau

U.S. Geological Survey

Water Resources Division

6770 S. Paradise Rd.

Las Vegas, NV 89119

Janet Wiley

International Technology Corporation

4330 S. Valley View

Suite 114

Las Vegas, NV 89103

Annie Kelley

State Documents Department

Nevada State Library

Capitol Complex

Carson City, NV 89710

Archives

Getchell Library

University of Nevada, Reno

Beverly Carter

MacKay School of Mines Library

University of Nevada, Reno

Document Section, Library

University of Nevada, Las Vegas

4505 Maryland Parkway

Las Vegas, NV 89154
Library (Stead)

Desert Research Institute

P.O. Box 60220

Reno, Nevada 89506-0220

Library

IT Corporation

4330 S. Valley View

Suite 114

Las Vegas, NV 89103

ATTN: Toni Miller

Library

Southern Nevada Science Center

Desert Research Institute

P.O. Box 19040

Las Vegas, NV 89132-0040

Public Reading Facility

Bechtel Nevada Corporation

P.O. Box 98521

Las Vegas, NV 89193-8521

Technical Information Resource Center

Nevada Operations Office

U.S. Department of Energy

P.O. Box 98518

Las Vegas, NV 89193-8518

Librarian

Water Resources Center Archives

410 O'Brien Hall

University of California

Berkeley, CA 94720-1718

Office of Scientific and Technical Information U.S. Department of Energy

P.O. Box 62

Oak Ridge, TN 37831-9939 